\title{
A Comparative Study of Livestock’s Name Between Ancient and Modern Yi Language of China*
}

\author{
YANG Liu-jin \\ Honghe University, Mengzi City, China
}

\begin{abstract}
The traditional pronunciations of domestic animal lexemes recorded in ancient Nisu(Yi) manuscripts differ significantly from the vernacular pronunciations of their modern counterparts. Thus, in the process of translating such texts, when a translator substitutes modern Nisu for ancient Nisu, not only can many of the characteristics of the original text be lost, but the original meaning may also be completely modified. Currently a number of specialists and scholars, both in China and elsewhere, are familiar with modern Nisu but have no such familiarity with the language's ancient forms. The paper grants Nisu researchers a better grasp of the differences between the language's ancient and modern forms in order to help others avoid mistakes in translating ancient Nisu manuscripts. This is accomplished through a brief comparative analysis of Nisu names for livestock and fowl—then and now.
\end{abstract}

Keywords: Yi Language, livestock, name

\section{Introduction}

Nisu is a Tibet-Burman language of the Ngwi branch which has been officially classified as an ethnic linguistic sub-branch of the Yi nationality in China. The Nisu retain use of their language in both spoken and written forms. The current population of the official Yi nationality stands at 7,776,230 (PCPC, 2002) and is distributed through Yunnan, Sichuan, Guangxi, and Guizhou Provinces. Traditionally, in China, the languages spoken by the Yi nationality have been divided into six major dialect regions: Northern, Eastern, Southern, Western, Central, and Southeastern (YYJS, 1987, pp. 242-245). Nisu falls within the Southern region of this schematic and has a population of over 1.5 million.

The Nisu Yi primarily inhabit the following counties of Yunnan Province: Shiping, Jianshui, Gejiu, Mengzi, Kaiyuan, Honghe, Yuanyang, Luchun, and Jinping counties of Honghe Hani-Yi Autonomous Prefecture; Eshan, Xinping, Yuanjiang, Yimen, Jiangchuan, and Tonghai counties of Yuxi Prefecture; Mojiang, Jiangcheng, and Pu'er counties of Simao Prefecture; and Shuangbai county of the Chuxiong Yi Autonomous Prefecture. In addition to these places, Jinning county of Kunming Prefecture and various parts of Wenshan Prefecture are also home to small Nisu populations.

\footnotetext{
* This paper is translated by Jamin Pelkey from La Trobe University, Melbourne. YANG Liu-jin, professor, International Hani/Akha Research Center, Honghe University.
} 
Ancient Nisu manuscripts from these locations include such writings as Wucha [ $\mathrm{\gamma u}^{21} \mathrm{ts}^{\mathrm{h}} \mathrm{a}^{21}$ ] (吴查), Maicha $\left[\mathrm{m}^{55} \mathrm{ts}^{\mathrm{h}} \mathrm{a}^{21}\right.$ ] (买查), the Lamobengsi Scriptures $\left[\mathrm{Ha}^{55} \mathrm{mo}^{21} \mathrm{pr}^{55} \mathrm{~s}^{33}\right]$ (腊莫崩史), the Great Flood, A Pathfinder's Guide, ${ }^{1}$ A Guide to Farewell Feasts, ${ }^{2}$ and Ancestral Genealogies. Such manuscripts claim that a man named Apudum $\left[\mathrm{a}^{55} \mathrm{p}^{\mathrm{h}} \mathrm{u}^{33} \mathrm{dur}^{21} \mathrm{mu}^{33}\right]$ is the common ancestor of the Nisu. Originally this patriarch is reported to have lived in a place called "Nate" $\left[\mathrm{na}^{55} \mathrm{t}^{\mathrm{h}} \mathrm{e}^{55}\right]$, the unverifiable location of an ancient Yi kingdom. From Na Te, these records report, the Nisu later migrated to the town of Guwo which is known today as Kunming City. From Kunming, the Nisu spread out to their current locations. Accordingly, Nisu religious beliefs, history, legend, customs, practices, and language, along with the Nisu writing system, which is based on the old Yi script, all concur by present day. Nevertheless, through time, numerous factors such as expulsion from homelands, geographical dispersion, and political and economic irregularities, have caused Nisu society to vary in linguistic, religious, and cultural domains. As the old saying goes, “百里不同风, 千里不同俗”. ${ }^{3}$ As such, this internally corresponding sub-branch has come to vary in cultural practice. However, the content recorded in ancient Nisu Yi manuscripts is internally consistent.

During the lengthy course of Yi social-historical development, the Yi script emerged as a product of ancestral wisdom and industry. In Han Chinese historical annals, Yi writings are referred to as "the Wei books" (韪书), and the script is referred to as “Cuan writing” (與文). With the script they had created the Nisu Yi went on to record such things as creation myths, folklore, historical legends, religious rites, folk customs, folk knowledge of the natural world, literature, and art—-thus forming a rich corpus of ancient manuscripts. In 1992, the Honghe Prefecture Ethnic Research Institute sent the author to a Nisu region of Honghe county to research ancient Nisu manuscripts. There the author soon discovered a folk-collection of some 1,300 volumes written in Nisu script — the majority of which had been hand copied before 1911. By the end of this period of manuscript investigation the author had done his best to read Nisu writings such as A Manual for Sacrificing Domesticated Animals (祭禽畜经), A Pathfinder’s Guide (指路经), A Guide for Farewell Feasts (饯行经), Genealogical Records (家谱), and A Marriage Song for Young Daughters (姑娘出嫁歌).

During this process, from among the manuscripts copied prior to 1911, the author found that the pronunciation of domestic animal lexemes read from the ancient script differed significantly from the vernacular pronunciation of their modern counterparts.

\section{Domestic Animal Names Recorded in Ancient Nisu Manuscripts}

Most of the Nisu manuscripts mentioned above were discovered in a village named Zuoluo (座落) located in Baohua district of Honghe Prefecture, Yunnan Province. Domestic animal names surfaced in this literature in three contexts each of which will be discussed in turn below.

\section{The Lamobengsi Records}

When a Nisu Yi individual dies, his or her family members have traditionally offered memorial sacrifices of livestock and fowl-domesticated animals including cows, goats, pigs, and chickens. Before slaughtering the

\footnotetext{
${ }^{1}\left[\mathbf{k o}^{21} \mathrm{mo}^{21} \mathrm{~s}^{33}\right]$, used for sending a spirit back to an ancestral home after death.

${ }^{2}$ Consulted for prescribed conventions related to a final meal before burial.

3 "Customs change with a hundred miles; conventions change with a thousand" or "Miles change manners".
} 
animals, the family ties them up in the courtyard of the deceased. Then a bimo $\left[\mathrm{pr}^{55} \mathrm{ma}^{21}\right]$ comes $^{4}$ and, sitting down beside a wicker table, he begins to read from the Lamobengsi scriptures. In Nisu, this text is pronounced $\left[\mathrm{fa}^{55} \mathrm{mo}^{21} \mathrm{pr}^{55} \mathrm{~s}^{33}\right]$ meaning “a guide to sacrificing domesticated animals” or, more aptly “祭禽畜经”. Mr. Li Bayikun (李八一昆), a Nisu Yi bimo from Daxinzhai village of Honghe county has preserved one such Lamobeng manuscript. The manuscript was hand copied in 1793. Sentences such as the following are recorded inside:

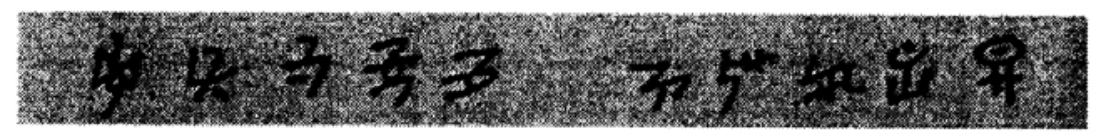

$$
\begin{array}{lc}
\left.\mathrm{ts}^{\mathrm{h}} \mathrm{a}^{21} \mathrm{~s}\right\urcorner^{21} \mathrm{ko}^{55} \mathrm{mo}^{55} \mathrm{p}^{\mathrm{h}} \mathrm{o}^{21} & \mathrm{no}^{21} \mathrm{be}^{33} \mathrm{na}^{21} \mathrm{no}^{55} \mathrm{ni}^{55} \\
\text { person die SPV high HON } & \text { IS speak 2S listen IPV }
\end{array}
$$

"Most dearly departed friend, listen now as I speak."

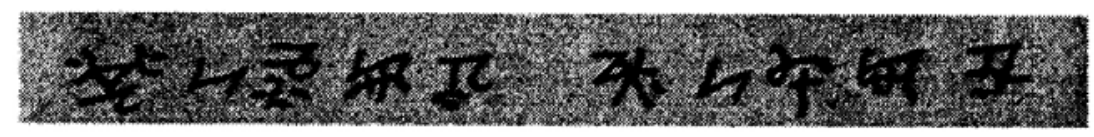

$$
\mathrm{mu}^{55} \mathrm{t}^{\mathrm{h}} \mathrm{i}^{21} \mathrm{ts}^{21} \mathrm{na}^{21} \mathrm{bi}^{21} \quad \mathrm{ts}^{21} \mathrm{t}^{\mathrm{h}} \mathrm{i}^{21} \mathrm{tu}^{33} \mathrm{na}^{21} \mathrm{bi}^{21}
$$

cow one CLF 2S give horse one CLF 2S give

"(We) offer to you a cow and a horse."

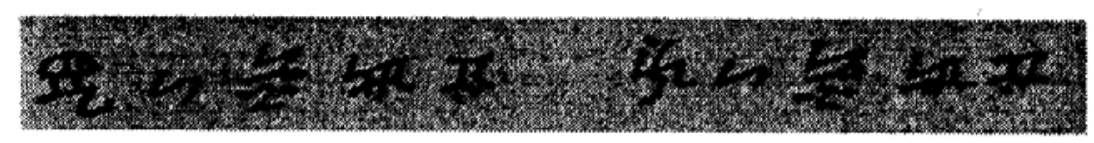

$$
\begin{gathered}
\text { nuu } \\
\text { pig } \mathrm{t}^{\mathrm{h}} \mathrm{i}^{21} \text { tse } \varepsilon^{55} \mathrm{na}^{21} \mathrm{bi}^{21} \quad \mathrm{bo}^{21} \mathrm{t}^{\mathrm{h}} \mathrm{i}^{21} \mathrm{ts}^{55} \mathrm{na}^{21} \mathrm{bi}^{21} \\
\text { one CLF 2S give sheep one CLF 2S give } \\
\text { "(We) offer to you a pig and a goat." }
\end{gathered}
$$

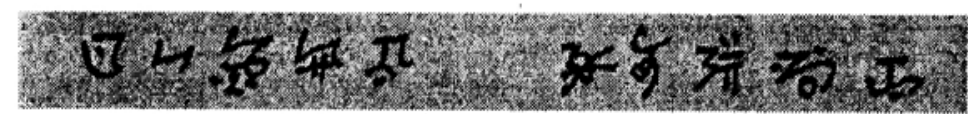

$$
\mathrm{yo}^{21} \mathrm{t}^{\mathrm{h}} \mathrm{i}^{21} \mathrm{tse}^{55} \mathrm{na}^{21} \mathrm{bi}^{21} \quad \mathrm{xe}^{21} \mathrm{k}^{\mathrm{h}} \mathrm{ur}^{55} \mathrm{de}^{33} \mathrm{Yo}^{21} \mathrm{nu}^{33}
$$

chicken one CLF $2 \mathrm{~S}$ give house LOC.in fowl livestock REAL

"(We) offer you a chicken. Of all the animals in our home."

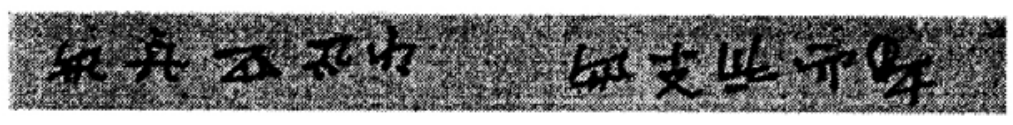

$$
\mathrm{na}^{21} \mathrm{k}^{\mathrm{h}} \varepsilon^{33} \mathrm{p}^{\mathrm{h}} \mathrm{e}^{33} \mathrm{bi}^{21} \mathrm{ti}^{21} \quad \mathrm{na}^{21} \mathrm{ni}^{33} \mathrm{t}^{\mathrm{h}} \mathrm{a}^{21} \mathrm{no}^{21} \mathrm{ga}^{33}
$$

2S LOC.above half give NML 2S heart NEG be.vexed PRG

"(We now) sacrifice more than half to you; do not be concerned."

\footnotetext{
4 “Bimo" (rendered 毕摩 in Chinese) in Nisu indicates a ceremonial priest or shaman-traditionally referred to as scholars of the old Yi script.
} 


\section{The Zuomosi Records}

Mr. Bai Fu (白福), a Nisu Yi bimo from Honghe county’s Baohua district seat, has preserved another dated manuscript of this nature entitled Zuomosi or A Pathfinder's Guide. The manuscript was hand transcribed in 1801 and was passed down to Mr. Bai from his grandfather. This particular type of scripture is recited by Nisu Yi bimos in order to send the souls of the deceased back to the ancestral homeland to be reunited with their ancestors. Included in the contents of the scriptures are the roads, place names, and village names that the ancestors once passed through. When acting as a Pathfinder, the bimo will walk up in front of the deceased body lying in a coffin, face the front door and read aloud from A Pathfinder's Guide. A selection from this book that contains domestic animal names is listed below:

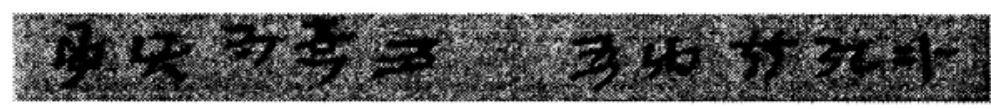

$$
\begin{array}{ll}
\mathrm{ts}^{\mathrm{h}} \mathrm{a}^{21} \mathrm{~s}^{21} \mathrm{ko}^{55} \mathrm{mo}^{55} \mathrm{p}^{\mathrm{h}} \mathrm{o}^{21} & \mathrm{no}^{33} \mathrm{mi}^{55} \mathrm{ko}^{21} \mathrm{mo}^{21} \mathrm{ka}^{55} \\
\text { person die SPV high HON } & \text { Hades road path LOC.on }
\end{array}
$$

"Most dearly departed friend, (walking) upon the roads of Hades,"

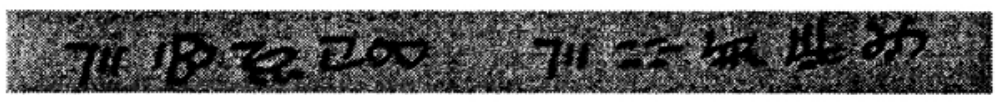

$$
\mathrm{me}^{33} \mathrm{ee}^{55} \mathrm{ts}^{\mathrm{h}} \mathrm{u}^{55} l \mathrm{e}^{33} \mathrm{pr}^{33} \quad \mathrm{me}^{33} \mathrm{k}^{\mathrm{h}} \varepsilon^{33} \mathrm{na}^{21} \mathrm{t}^{\mathrm{h}} \mathrm{a}^{21} \mathrm{ku}^{33}
$$

fire flame burn come NML fire LOC.above 2S PHB afraid

"(When) the flames threaten to burn you, do not be afraid:"

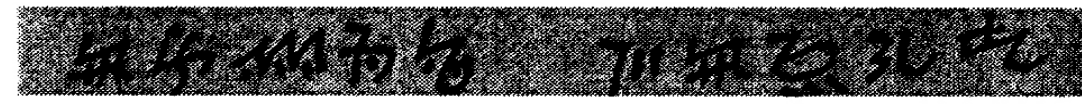

$$
\begin{array}{lc}
\mathrm{na}^{21} \mathrm{bo}^{21} \mathrm{\phi i}^{33} \mathrm{go}^{21} \mathrm{de}^{21} & \mathrm{me}^{33} \mathrm{na}^{21} \mathrm{ts}^{\mathrm{h}} \mathrm{u}^{55} \mathrm{ma}^{21} \mathrm{ku}^{21} \\
2 \mathrm{~S} \text { goat skin wrap PFV } & \text { fire } 2 \mathrm{~S} \text { burn NEG able }
\end{array}
$$

"Wrap goat skins around you (so) the flames will not burn you."

\section{The Nehongjieduhou Records}

A third Nisu Yi bimo from Honghe county, Mr. Pu Libao (普里宝), of Hazhi village, Shitouzhai district, has preserved a manuscript entitled, “A Marriage Song for Young Daughters”, pronounced $n e^{55} \mathrm{xo}^{55} \mathrm{dz} \mathbf{e}^{21} \mathrm{du}^{33} \mathrm{xr}^{21}$ in Nisu. The manuscript was hand copied in 1892 and then passed down to Mr. Pu from his great grandfather Ah Sanyu (阿三于). The contents of this manuscript primarily record ancient Nisu Yi “marriage marketing” scenarios. In times past a young Nisu female was unable to marry whomever she pleased; instead, the decision was entirely up to the girl's parents and was also tightly controlled along societal class lines. In many cases such a union might also be politically motivated. Under such circumstances girls had no authority to be involved in the momentous matters of their own marriage. Their only choice was "the parent's will and the matchmaker's word" which might well become, "if you marry a pig adapt to the pigs; if you marry a dog, adapt to the dogs". 5 Such a bride would not even be able to lean anything about her prospective spouse until a few

5 “父母之命，媒约之言” ……“嫁猪随猪、嫁狗随狗” 
days before the wedding. As a result, females were dissatisfied with their own marriages and would recount this song in tears. The song still preserves a number of ancient Nisu pronunciations. An excerpt is listed below:

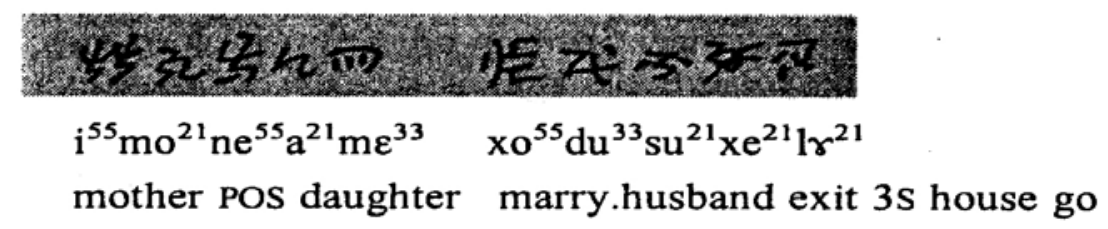

"A mother's daughter marries, leaves home, and goes to her groom's house"

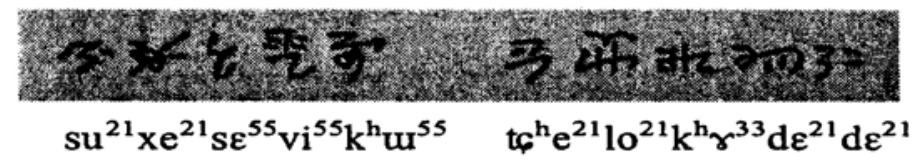

3s house gold splendor LOC.in millet storehouse full full

"In his marvelous house, there is millet heaped high in the granary,"

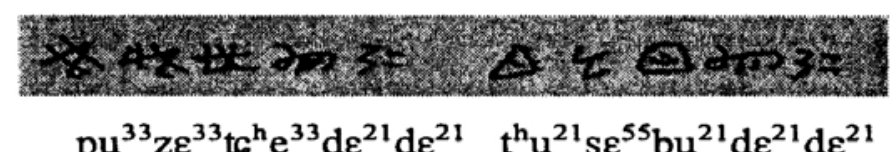

$\mathrm{pu}^{33} \mathrm{z}^{33} \mathrm{tc}^{\mathrm{h}} \mathrm{e}^{33} \mathrm{~d} \varepsilon^{21} \mathrm{~d} \varepsilon^{21} \quad \mathrm{t}^{\mathrm{h}} \mathrm{u}^{21} \mathrm{~s} \varepsilon^{55} \mathrm{bu}^{21} \mathrm{~d} \varepsilon^{21} \mathrm{~d} \varepsilon^{21}$

silk shirt basket full full gold silver ceramic.jar full full

"Baskets stuffed full with silk shirts, jars packed with silver and gold,"

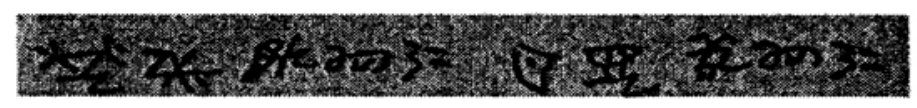

$$
\mathrm{mu}^{55} \mathrm{ts}^{\mathrm{h}} \mathrm{r}^{21} \mathrm{la}^{33} \mathrm{~d} \varepsilon^{21} \mathrm{~d}^{21} \quad \mathrm{yo}^{21} \mathrm{nu}^{55} \mathrm{de}^{21} \mathrm{~d}^{21} \mathrm{~d} \varepsilon^{21}
$$

cow horse stall full full chicken pig courtyard full full

"Stalls jammed full with cows and horses, courtyards brimming with chickens and pigs..."

The three excerpts listed in this section have been taken from ancient Nisu manuscript versions each of which was hand-transcribed in three different eras—each separated by a significant span of years. The Nisu Yi lexemes for livestock and fowl recorded in these documents have ancient pronunciations that are, by present day, unused and unknown by all but a handful of bimos - the scholars of the old Yi script, and their apprentices - those whom they are mentoring of their own accord. In these manuscripts animal names are given the following pronunciations when read aloud: "cow" is read as $m u^{55}$, "horse" is read as $t \boldsymbol{s}^{\boldsymbol{h}} \boldsymbol{\gamma}^{2 l}$, "pig" is pronounced $n u^{55}$, "goat" as $b o^{21}$, and "chicken" as $y o^{2 l}$.

\section{A Diachronic Comparison of Domestic Animal Names}

As was mentioned above, the long history of Nisu Yi manuscript production had already come to an end by the founding of the People's Republic of China in 1949. Now even hand copies that are made of Nisu Yi documents are referred to collectively with the old as "ancient manuscripts". Those speaking the contemporary vernacular have produced a form of speech useful for daily life. Language is essentially a social phenomenon; it comes into being as a given society is given birth and continues to develop hand-in-hand with that particular society. Naturally, then, Nisu Yi has also continued to develop and change, and accordingly, a significant degree of difference exists between modern pronunciations of domestic animal names and the pronunciations of 
the same lexemes in ancient manuscripts. This is the diachronic distinction that will be considered in the remainder of the paper.

Note the lexemes in Figure 1. With the exception of "dog”, which has consistent pronunciations between manuscript and modern forms, the rest of the domestic animal names have widely different forms-not only is there tonal change, but the initials and finals are completely changed as well.

\begin{tabular}{|c|c|c|c|}
\hline & $\begin{array}{l}\text { Nisu Manuscript } \\
\text { Pronunciation }\end{array}$ & $\begin{array}{c}\text { Modern Nisu } \\
\text { Pronunciation }\end{array}$ & Notes \\
\hline 'cow' & $\mathrm{mu}^{5 s}$ & $n r^{33}$ & $\begin{array}{l}\text { general lexeme used } \\
\text { of both field cows and } \\
\text { water buffaloes }\end{array}$ \\
\hline 'horse' & $\operatorname{tss}^{21}$ & $\mathrm{mo}^{33}$ & \\
\hline 'pig' & $\mathrm{nu}^{55}$ & $\mathrm{vẹ}^{21}$ & \\
\hline 'goat' & $b^{21}$ & $t^{\mathrm{h}} ?^{21}$ & \\
\hline 'sheep' & $b o^{21}$ & $\mathrm{xa}^{21}$ & \\
\hline 'dog' & $t^{\mathrm{h}^{\mathrm{h}} \mathrm{j}^{33}}$ & $\operatorname{tsc}^{h^{h^{33}}}$ & $\begin{array}{l}\text { manuscript and } \\
\text { modern forms have } \\
\text { same pronunciation }\end{array}$ \\
\hline
\end{tabular}

Figure 1. Diachronic comparison of domestic animal name pronunciations.

\section{The Development of "Cow"}

Both in ancient Nisu songs and in the ancient Nisu manuscript Lamobengsi, no distinction is made between "water buffalo" and "field cow" (黄牛)—both being jointly rendered under a common form pronounced as $m u^{55}$ "cow". Sometime between the 18th and 20th centuries, a new "cow" lexeme $\mathbf{b r}^{33}$ began to appear and gained widespread use in Nisu manuscripts. In addition, "water buffalo" and "field cow" emerged as individual lexemes $2 e^{33}$ and $\mathbf{n g}^{33} \mathbf{n g}^{55}$ respectively. By present day, the vast majority of Nisu speakers-being unable to read the ancient manuscripts—are, as a result, only aware of these later innovations. Nevertheless, a handful of Yi script scholars—-the Nisu bimos—still know that the Nisu ancients called cows $m u^{55}$.

\section{The Development of "Horse"}

Ancient Nisu manuscripts record "horse" as $t s^{h} \gamma^{2 l}$. This lexeme was not used exclusively in reference to horses, however, instead being used as a more general term encompassing horses, mules, and donkeys. Nevertheless, one can still claim that $t s^{h} \gamma^{2 \downarrow}$ is the most ancient [known] Nisu lexeme for "horse". Afterwards, though, following the currents of social development, a new "horse" lexeme $m o^{33}$ appeared in both manuscripts Nisu and spoken Nisu; likewise, “donkey” came to be called $l e^{21} \mathrm{ka}^{55 t} \mathrm{ts} \mathrm{q}^{33}$ and "mule" took the name ${ } a^{55} t \mathbf{L}^{33}$ [Chinese loan?]. Modern Nisu speakers are unaware of the earlier form and use only the latter three lexemes by present day to distinguish horses, donkeys and mules.

\section{The Development of "Pig"}

The ancient Nisu manuscripts Zuodengsi (昨灯史), Pupingdengsi (普评灯史), and other documents use $n u u^{55}$ as a "pig" lexeme. Once again, however, between the 18th and 20th centuries, a new "pig" scribal 
practice was adopted which emerged in favor of $v \boldsymbol{e}^{21}, \boldsymbol{v} \underline{e}^{21} n e^{33}$ and other similar forms for this lexeme.

\section{The Development of “Goat” and "Sheep”}

The ancient Nisu manuscripts Zuomosi (昨莫史), Lamobengsi (腊莫崩史), Xianzhangzhongsi (贤张钟 史), and other documents include both "goat” and “sheep” under the general lexeme $b o^{21}$ (i.e., these documents made no distinction between the two). Later manuscripts, along with colloquial Nisu, distinguished the two lexically as $t \boldsymbol{s}^{\underline{h}} \underline{1}^{21}$ "goat" and $x a^{21}$ "sheep". Following this line of reasoning, we can affirm that $b o^{21}$, is an ancient Nisu form while $t \boldsymbol{s}^{\boldsymbol{h}^{21}}$ and $x a^{21}$ reflect more modern Nisu innovations.

\section{The Development of "Dog"}

Unlike other animal names examined above, the "dog" lexeme, $t{ }^{h} i^{33}$, does not show variation between its pronunciation in ancient manuscripts, and its pronunciation in orally transmitted folktales such as "the dog and the moon”, “eating new rice”, “dogs and people”, “tigers and dogs”, “cats and dogs”, etc.

\section{Conclusion}

The ancient forms of the domestic animal names listed in Figure 1 above are based on pronunciations of the lexemes in ancient texts like Maicha, Wucha, Zuomosi, Qiunianzuozuosi, Lamobengsi, Xianzhangzhongsi, Zuohasi, Hongjianjiamaodihou, and others-documents that were hand copied during the Qing Dynasty, between 1736 to 1849. In spite of being copied so late, they nevertheless include material that represents an age old ancestral history resistant to change. As such the manuscript pronunciations in Figure $l$ are recommended as reliable. Some outside researchers—considering the ancient Yi manuscripts to be useful only for superstitious, feudalistic purposes - are not clear on the facts. Some may even think that the pronunciations of animal names recorded in them are, thereby, be unreliable. This viewpoint, however, would not capture the whole picture. The ancient Nisu manuscripts approached from the outside are indeed evanescent; nevertheless, the only substantial viewpoint to hold toward them considers their essential nature. This is a viewpoint that cannot be neglected. When a Nisu Yi bimo performs a sacrificial rite for a deceased person, his readings are in actual fact depicting the ancient migration route of the Nisu ancestors. The history of their experience, the food they ate, the plants they raised, along with the names they called their livestock and fowl are available to us for understanding the foundational features of their past. As such, since the pronunciations of animal names recorded in ancient Nisu manuscripts differ so significantly from their modern counterparts-most differing widely in their initials, finals, and tone alike — we can hold that the manuscript forms do, in fact, represent the ancient Nisu forms.

This paper is intended to serve as a reference for translators of ancient Yi manuscripts. The Qing Dynasty Chinese translator Yan Fu (严复, 1853-1921) advocated three principles of translation, viz., Fidelity (信), Expression (达), and Elegance (雅). Yan Fu offers his own specific explication of these principles in his work Tian yan Lun (《天演论. 译例言》) stating, “译事三难 : 信、达、雅。求信已大难矣, 顾信矣不达, 虽译 犹不译也, 则达尚焉。” (as cited in LUO, 1989, pp. 2-3). " “Fidelity” represents a concern for faithfulness to the original text-expressing the factual and thematic content of the original subject matter with integrity and accuracy. "Expression" represents a translation that is clearly understandable and free flowing-with no

${ }^{6}$ Translator's note: Under the circumstances, deem it unwise to attempt translation of this quote. 
literalisms, mechanical expressions, or incoherent effects. "Elegance” represents the need for the translator to preserve the flavor and style of the original. Only in this way can one guarantee the quality of a translation and ensure that it meets the mark.

At present some translators of ancient Yi manuscripts only understand contemporary Yi and not its ancient forms: Ultimately, the output of such translators cannot measure up to the required standards. In order to become a true translator of ancient Yi manuscripts, one should first seek a deep understanding and a meticulous mastery of the original content recorded in the manuscripts; then, with faithfulness to the original, he/she should accurately express the factual and thematic content in a holistic translation. Only in this way can we ensure a quality translation and guarantee that we leave something of value to future generations.

\section{References}

Compiling Group of An outline of Yi History. (2009). An outline of Yi history. Beijing: Nationalities Publishing House.

FANG, G. Y. (1984). A history of the people. Chengdu: Sichuan Minorities Press.

KONG, Y., LI, B. Q., \& BAI, K. N. (Trans.). (1985). The Duo festival of the Nisu(Yi) People. Kunming: Yunnan Nationalities Publishing House.

LUO, X. D. (1989). A guide to self-study on Japanese-Chinese translation. Beijing: Academic Periodical Press.

Nienubaxi. (1984). Selections from long narrative epic of the Yi People. Kunming: Yunnan Nationalities Publishing House.

PCPC. (2002). Tabulation on the 2000 population census of the People's Republic of China (Vol. 1). Beijing: China Statistics Press.

PU, X. W., \& LIANG, H. (Trans.). (1987). Books of Chashila. Kunming: Yunnan Nationalities Publishing House.

Team of Compiling the History of the Yi People. (1987). A brief history of the Yi people. Kunming: Yunnan People's Press.

YANG, L. J. (1998). The etiquette in life of the Nisu(Yi) people. Kunming: Yunnan Nationalities Publishing House.

YANG, L. J. (2006). The migratory history of the Nisu(Yi) people in Honghe. Beijing: Ethnic Publishing House.

YANG, L. J. (Trans.). (2004). Canon of showing the routes of Honghe Yi People. Kunming: Yunnan People’s Press.

YANG, L. J., PU, X. W., LIANG, H., PU, Z. K., \& Luoxiwuge. (Trans.). (1999). The canon of dragon worship of the the Yi people. Kunming: Yunnan Nationalities Publishing House. 